However, I regret that you missed the opportunity to point out that human reproduction by in vitro fertilization (IVF) also involves the fertilization of the egg and the early development of the embryo, and that large numbers of such embryos are destroyed.

There is thus no ethical difference between IVF and creating embryonic stem cells, as both require the creation and destruction of embryos. One can be, for religious reasons, against both, but not rationally against one and not the other. IVF has been of enormous value and so too will stem cells.

\section{Lewis Wolpert}

Department of Anatomy and Developmental Biology, University College London, Gower Street, London WC1E 6BT, UK

\section{Science archives should remain in public hands}

Sir - We would like to correct any impression of neglect of Britain's rich scientific archive heritage that might have been given by the News feature "The History Man", about the US private collector Jeremy Norman (Nature 411, 732; 2001). On the contrary, the United Kingdom is fortunate in having universities and national institutions that show an active interest in collecting science archives.

The Royal Society and the Wellcome Trust, for example, have supported the preservation and cataloguing of such materials over many years. The Wellcome Trust has recently established a Research Resources in Medical History scheme, with $\mathfrak{E} 1$ million (\$US1.4 million) for the year 2001-2002 to support important documentary collections.

Archives in universities, including contemporary science archives, have benefited from major funding programmes run by the Higher Education Funding Councils. A recent award from the UK Heritage Lottery Fund will allow a group of science institutions to mount a large number of catalogues of scientists' archives on the web as part of Access to Archives, a vast online catalogue at http://www.a2a.pro.gov.uk.

Many important personal scientific papers are held in libraries and repositories in the United Kingdom, some having been catalogued by the National Cataloguing Unit for the Archives of Contemporary Scientists (NCUACS). This work is supported by several scientific societies, trusts and foundations, preserving a significant part of contemporary British science and biomedicine in a major collaborative effort.
For the long-term benefit, such papers are best housed in properly resourced public repositories in their country of origin, rather than in private hands.

Archivists, who will always have to struggle to maintain their budgets in a competitive world, will be greatly helped by widespread recognition of that basic principle. Peter Harper ${ }^{\star}$, Julia Sheppard $\dagger$ ${ }^{*}$ NCUACS, University Library, University of Bath, Claverton Down, Bath BA2 7AY, UK †Wellcome Library, 183 Euston Road, London NW1 2BE, UK

\section{Nature's laws revealed in rhyming couplets}

Sir - I would like to add to Fleming Carswell's interesting Correspondence (Nature 411, 885; 2001) about the relevance of poetry to scientists today by mentioning a few of the scientists who in the past published their work as poetry.

Charles Darwin's grandfather Erasmus Darwin (1731-1802), for example, wrote up some of his own evolutionary and other theories in Popean couplets, perhaps best known in The Temple of Nature:

Organic life beneath the shoreless waves Was born and nurs'd in Ocean's pearly caves;

First forms minute, unseen by spheric glass,

Move on the mud, or pierce the watery

mass.

In the same poem he describes 'the Maiden Truffle' as an example of reproduction without a sexual partner:

So the lone Truffle, lodged beneath the earth,

Shoots from paternal stems the tuberous birth.

No stamen-males ascend, and breathe

above,

No seed-born offspring lives by female

love.

These influenced not only his grandson but also the English romantic poets, to such an extent that Samuel Coleridge used the term "Darwinizing" to describe such poetic theorizing.

Alexander Pope (1688-1744) himself asked a cosmological question in his Essay on Man, Epistle 1, which is only now being answered:

Observe how System into System runs.

What other Planets circle other Suns?

Later in the same epistle, he seemed to lay the foundation of statistics:

All Nature is but Art unknown to thee;

All Chance, Direction which thou canst

not see.

Pope also wrote in his Epitaph for Sir Isaac Newton (perhaps anticipating the need for this journal?):
Nature, and Nature's laws lay hid in night

God said, Let Newton be! and all was light.

to which J. C. Squire (1884-1958) in his Epigrams replied:

It did not last: the Devil howling " $\mathrm{Ho!}$

Let Einstein be!", restored the status quo.

The advice Pope gave in his Essay on Criticism could apply to Nature's referees:

Let such teach others who themselves excel And censure freely who have written well.

Modern poets offer yet more of the stimulating and enjoyable reasons why, as Carswell states, scientists should "bother about poetry". Not least among these are the poetry of Edwin Morgan (to be found, for example, in Stargate, Third Eye Centre, Glasgow, 1979); Miroslav Holub (for example, Vanishing Lung Syndrome, Faber and Faber, London, 1990); and Ronald Duncan (for example, Man: The Complete Cantos, Rebel Press, London, 1970).

\section{N. C. Craig Sharp}

Department of Sport Sciences, Brunel University, Borough Road, Isleworth, Middlesex TW7 5DU, UK

\section{Enthusiasm ran ahead of discoveries still to come}

Sir - In your excellent News story "Epidemiology gains an ally in bioweapons surveillance project" (Nature 411, 228; 2001), summarizing the rapid syndrome validation project (RSVP) for early 'syndrome-based' epidemiological reporting, you faithfully reported my statement that "This rapid reporting already appears to have this year averted two outbreaks of hepatitis A" and that antiviral-drug prescription frequency may have been altered.

This information was incorrect. I based these statements on early, anecdotal evidence that I cannot fully support. I should have checked my sources more carefully. I regret the error, and take full responsibility for it. All other aspects of the News story are accurate.

I look forward to reporting, in a future paper, the benefits and downsides of the novel systematic approach to disease reporting that we are taking at RSVP, once we have accumulated a sufficiently large database. We are fortunate to have funding from the US Department of Energy to expand the project to multiple reporting sites in various clinical settings, including non-academic medical clinics and publichealth clinics on both sides of the Mexico-US border.

Alan P. Zelicoff

Sandia National Laboratories, PO Box 5800,

Albuquerque, New Mexico 87185, USA 